\title{
Chronic HIV infection and health related quality of life in resource poor settings-an assessment from South East Nigeria
}

\author{
Chinwe Laura Onyekonwu ${ }^{1}$, Tonia Chinyelu Onyeka ${ }^{2}$, Nwatu Chidimma Brenda ${ }^{3}$, \\ Uchenna Nkemdilim Ijoma ${ }^{3}$, Ngozichukwu Nneka Unaogu ${ }^{4}$, Ikenna Obinwanne Onwuekwe ${ }^{3}$, \\ Fred Ugwumba ${ }^{5}$, Chidimma Rhoda Nwutobo ${ }^{6}$, Chioma Victoria Nwachukwu ${ }^{7}$
}

1. Sub-Department of Dermatology, College of Medicine, University of Nigeria, Ituku-Ozalla Campus, Enugu, Nigeria.

2. Department of Anaesthesia/Pain and palliative Care Unit, Multidisciplinary Oncology Center, College of Medicine, UNTH, Ituku-Ozalla Campus, Enugu, Nigeria.

3. Department of Medicine, College of Medicine, University of Nigeria, Ituku-Ozalla Campus, Enugu, Nigeria.

4. Federal Neuropsychiatric Hospital, Enugu, Nigeria.

5 Urology Unit, Department of Surgery, College of Medicine, University of Nigeria, Ituku-Ozalla Campus, Enugu, Nigeria.

6. Department of Medicine, University of Nigeria Teaching Hospital, Ituku-Ozalla.

7. Department of Medical Physiology, College of Medicine, University of Nigeria, Enugu Campus, Enugu, Nigeria.

\begin{abstract}
Background: Health-related quality of life reflects a patient's general subjective perception of the effect of an illness or intervention on physical, psychological and social aspects of daily life. HIV infection is a major public health problem especially in developing countries where poor health infrastructure and poverty are prevalent. This paper addresses the quality of life in patients with chronic HIV infection in South East Nigeria and addresses issues that may help improve the current situation.

Methods: A cross-sectional survey was carried out at the University of Nigeria Teaching Hospital, Enugu, to assess patients with HIV receiving antiretroviral therapy (ART) using a validated structured questionnaire (WHOQoL-BREF). Ethical clearance for the study was obtained. Study period was from October - December, 2017. Data obtained was analysed.

Results: A total of 389 HIV patients consented to the study. Over 70\% were aged 18- 45 years and majority were females. Females had a higher quality of life score with respect to the domain of psychological health while males had a higher score with respect to the environmental domain. Older age and presence of co-morbidities were significantly associated with affectation of physical health while younger age was associated with affectation of psychological health domain.

Conclusion: HIV impairs the quality of life for affected individuals in South East Nigeria especially across the domains of physical and psychological health. No age group is spared. The presence of co-morbidities significantly reduces quality of life in these patients. Younger patients may require mental health services in the management of their disease.
\end{abstract}

Keywords: HIV, quality of life, South East Nigeria.

DOI: https://dx.doi.org/10.4314/ahs.v20i1.15

Cite as: Onyekonwu CL, Onyeka TC, Brenda NC, Ijoma UN, Unaogu NN, Onwuekwe IO, et al. Chronic HIV infection and health related quality of life in resource poor settings-an assessment from South East Nigeria. Afri Health Sci. 2020;20(1):102-13. https:/ / dx.doi.org/ 10.4314/ abs.v20i1.15

\section{Corresponding author:}

Tonia Chinyelu Onyeka,

Department of Anaesthesia/

Pain and palliative Care Unit,

Multidisciplinary Oncology Center,

College of Medicine, UNTH,

Ituku-Ozalla Campus, Enugu, Nigeria

Email: tonia.onyeka@unn.edu.ng

\section{Introduction}

Human immunodeficiency virus (HIV) infection is a chronic disease but advances in treatment over the past three decades have favorably improved its outcome as a chronic disease ${ }^{1}$. The HIV epidemic in Nigeria affects all population groups and geographic areas of the country; it is said to be the second largest epidemic globally ${ }^{2}$. Although the prevalence of HIV infection in Nigeria is currently estimated at $3.2 \%$, this figure is high consider- 
ing that Nigeria is a very populous nation ${ }^{3}$. Enugu state, where the study was conducted, has prevalence between $4.1 \%$ and $6.0 \%{ }^{3}$.

$\mathrm{HIV}$ infection is a major public health problem especially in developing countries where poor health infrastructure and poverty are prevalent. In Nigeria, health care is financed through different sources including but not limited to tax revenue, out-of-pocket payments (OOPS), donor funding, and health insurance 4 . Out-of-pocket spending (OOPS) is the major payment strategy for healthcare, not only in Nigeria but also in developing countries ${ }^{5,6}$. These out-of-pocket spending expenses include over-the-counter payments for medications and fees for consultations and procedures ${ }^{7}$. The World Health Organisation (WHO) in 2010 estimated that approximately 100 million people are pushed below the poverty line each year by payments for healthcare ${ }^{6}$.

Apart from reducing the risk of HIV transmission, combination antiretroviral therapy (cART) improves health and prolongs the life of affected individuals. When used properly, ART leads to rapid control of HIV and partial restoration of immune function. However, treatment does not fully restore immune health; rather, some inflammatory and/or immunodeficiency complications may occur as a consequence ${ }^{1}$. These HIV-associated complications which include cardiovascular diseases, cancers and complications from cumulative toxic exposure to antiretroviral drugs, among others, lead to new chronic diseases that may span for several decades in some of these patients.

Although evidence indicates that people diagnosed with $\mathrm{HIV}$, not only in resource-rich countries but also in Africa and are receiving suitable treatment with cART have a life expectancy that is almost comparable to that of people without HIV, people living with HIV have significantly lower health-related quality of life (HRQoL) than the general population ${ }^{8,9}$. HRQoL is an essential health care indicator for people living with chronic illnesses; studies usually show two major dimensions of HRQoL: physical and mental ${ }^{10,11}$.

HRQoL is characterized by feelings of wellbeing, control and autonomy, a positive self-perception, a sense of belonging, participation in enjoyable and meaningful activity and a positive view of the future ${ }^{12}$. While anxiety and depression are major factors affecting $\mathrm{HRQOL}^{13}$, the stigma of becoming HIV positive and the significant losses of self-esteem, friendships, family support and help, around the time of diagnosis may cause persistent adjustment disorders that may lead to serious consequences ${ }^{14}$. Both mental and physical HRQoL decrease with more advanced stage of the disease $e^{15,16}$ and with lower socioeconomic status ${ }^{17}$.

Several HRQoL studies in HIV patients have been carried out in different climes. In a cross-sectional baseline survey of the HPTN 071(PopART) trial, the ability of ART in successfully reducing the inequalities in HRQoL between HIV-positive and HIV-negative individuals in a general population sample was demonstrated ${ }^{18}$. While Mafirakureva et $\mathrm{al}^{19}$ observed that income, education and employment were positively and significantly associated with HRQoL in HIV/AIDS patients on antiretroviral therapy at a tertiary care facility in Zimbabwe, Akinboro et al, in Southwestern Nigeria, found that high CD4 count, adherence to ART, being in a marital relationship and absence of concomitant tuberculosis impacted positively on the quality of life of their study participants ${ }^{20}$.

UNTH, Ituku-Ozalla is a tertiary center for healthcare in the south-east and in the early years of HIV care and treatment, was one of the largest centers for care under the AIDS Prevention Initiative in Nigeria (APIN). It is assumed that similar factors may affect the quality of life among HIV patients on treatment in other centers as well as in this facility. However, no study has been carried out on HRQoL among HIV patients in the University of Nigeria Teaching Hospital, Ituku-Ozalla. This study aims to bridge that gap.

\section{Justification for the study}

With the discovery of highly active combination antiretroviral drugs, HIV infection is no longer a death sentence but rather a chronic, life-long disease. It is therefore important to identify factors that may worsen the quality of life of patients living with HIV/AIDS and measures that will improve their overall wellbeing.

\section{Aims and Objectives}

Aim: To determine the health related quality of life of HIV patients accessing treatment and care in the HIV Clinic of University of Nigeria Teaching Hospital, Ituku-Ozalla, Enugu

\section{Objectives:}

1. To assess the quality of life of HIV patients accessing care in UNTH, Ituku-Ozalla, Enugu in four domains - 
physical health, psychological well-being, social relationships and interactions with their immediate environment . 2. To explore the association between sociodemographic variables of study participants and the domains of quality of life.

3. To explore the association between sociodemographic characteristics and clinical predictors of quality of life in the four domains among people with HIV/AIDS.

\section{Materials and Methods}

Study Site: This study was a single-site cross-sectional survey conducted at the University of Nigeria Teaching Hospital (UNTH) HIV clinic situated at the permanent site of UNTH at Ituku-Ozalla, Enugu, and the prime public tertiary hospital in South East Nigeria. This clinic commenced services in 2002 as part of the Federal Government of Nigeria response to the HIV infection. When the PEPFAR initiative was introduced, the clinic became the largest center for HIV Care and treatment for adults, pregnant women and children in the South-Eastern part of Nigeria receiving patients from all over the south-east and environs. Presently, the clinic has over 4,000 clients enrolled in care, excluding children and adolescents.

\section{Study Participants}

Adult ( $\geq 18$ years of age) patients with HIV infection accessing care at the HIV clinic were consecutively recruited over a 12 week-period from October to December 2017, after giving both oral and written informed consent. Ethical clearance for this study was given by the institution's health research and ethics committee.

\section{Study design}

This cross-sectional and descriptive study employed the World Health Organization Quality of Life Questionnaire -short version (WHOQoL-BREF) instrument comprising 26 questions drawn from four quality of life (QoL) domains.

\section{Sampling}

Sampling was by convenience sampling. All patients who consented to participate in the study were consecutively recruited within the targeted study period between October and December, 2017. A total of 399 patients were invited to participate but only 389 consented, a response rate of $97.5 \%$.

\section{Study procedure}

Consecutive subjects with confirmed HIV infection and on ART, being managed at the HIV clinic of the University of Nigeria Teaching Hospital were recruited over twelve weeks. Informed consent, socio-demographic and some basic clinical data were collected. This included information on prior hospitalizations, presence of comorbidities and history of HIV infection in any family member.

This information was considered to be relevant as prior hospitalizations may be indicative of patient's immunological status since the researchers did not have access to patients' CD4 count and HIV Viral load assays. Presence of comorbidities may worsen patients' clinical condition significantly. A family history of HIV infection was also explored as having other family members may indicate worsening of family's socioeconomic status.

Variable baseline was at study entry. All patients had been on antiretroviral therapy for at least one year prior to the study.

The WHOQoL-BREF instrument was interviewer-administered and transformed scores calculated for the overall quality of life and for the four domains of quality of life. The study instrument was selected because it has been used in other studies and has been validated in the south western part of Nigeria ${ }^{21-23}$. All interviews were face-to-face and carried out by two trained researchers in order to reduce bias.

A score below 78 was considered poor; this being the mean cut-off score predicting poor quality of life among apparently normal typical Nigerian adults. ${ }^{20}$

\section{Data analysis}

The questionnaire assessed QoL of the patients in four domains - physical health (domain 1); psychological well-being (domain 2), social relationships (domain 3), and interactions with their immediate environment (domain 4). Patients rated all items on a 5-point Likerttype scale, based on their individual perception. Domain scores were then calculated, after transforming the scores recorded for negative perception and scaled in a positive direction, with higher scores representing a higher QoL and vice versa. Mean scores were subsequently equated to scores obtained from the initial WHOQoL-100 questionnaire (by multiplying scores by 4), from where the shortened WHOQoL-BREF was adapted. 
Data was analyzed using the International Business Machine-Statistical Package for Social Sciences (IBM-SPSS version 23) Illinois, Chicago. Data were first scrutinized for incorrectly filled information and cleaned using frequencies. Group comparisons were done using one-way analysis of variance and independent t-test were appropriate (continuous variables). Socio-demographic and clinical predictors of health-related quality of life were analyzed using multiple regression analysis. All test were two-tailed and the level of significance was set at $\mathrm{p}<0.05$.

\section{Results}

Table 1 shows the sociodemographic characteristics of the study participants. The highest age frequency was between ages 18 - 45 years $(73.3 \%)$. Majority of the subjects were females and about half of them were married. Only $17.5 \%$ of participants were professionals; half were traders and artisans while only $27 \%$ had attained a tertiary education. About half of these patients earn NGN10, 000 (\$30 equivalent) or less monthly. Study participants had a mean number of 3.4 dependants and the average number of hospitalizations in the past year was 1.7 times.

Table 1: Socio-demographic characteristics of the participants with HIV/AIDS

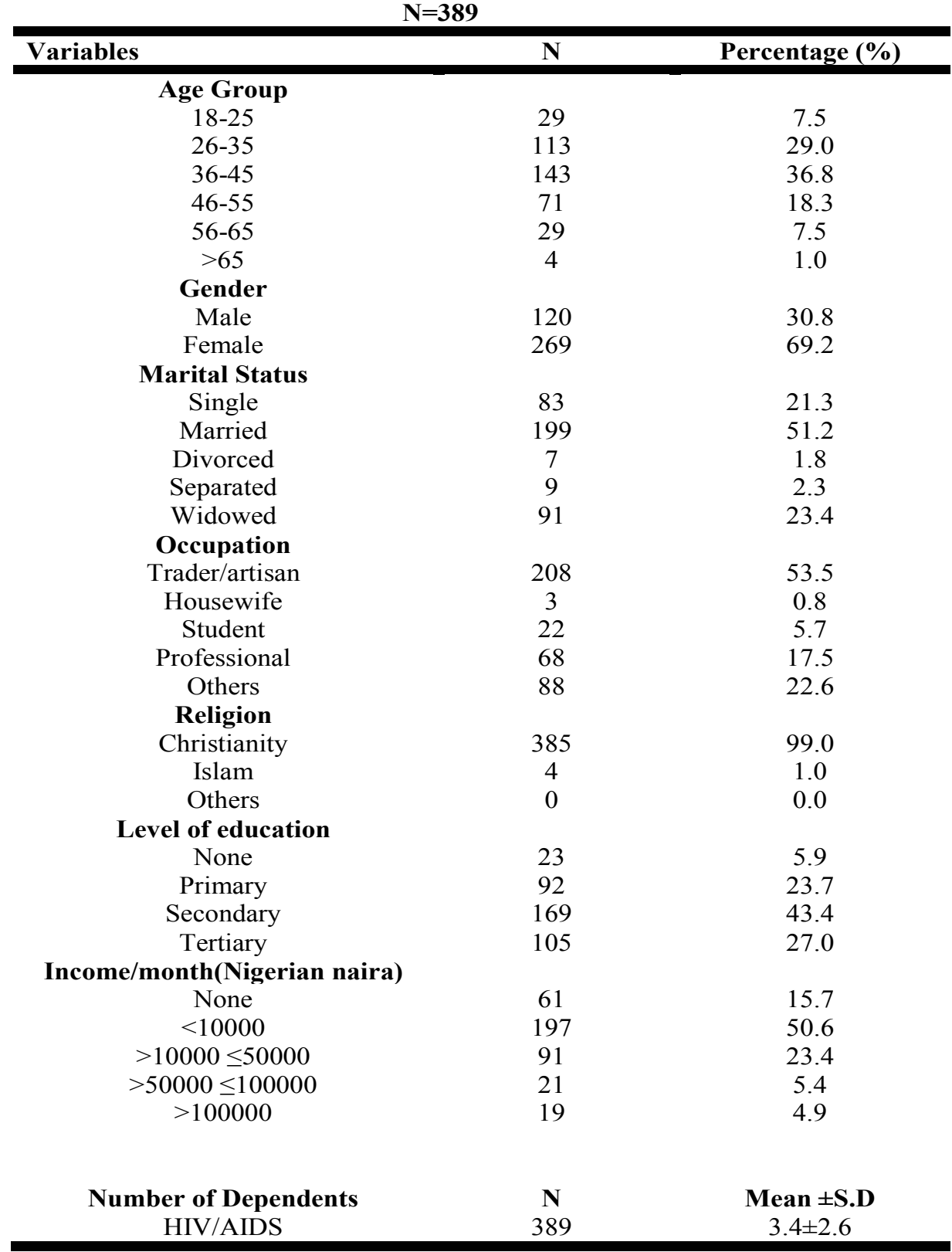


Among the study participants, 33.4\% had family members who were also seropositive (Table 2). Presence of

co-morbid medical conditions was seen in $13.6 \%$ of participants and only $5.7 \%$ of patients had medical insurance coverage (Table 2).

Table 2: Clinical characteristics of the participants with HIV/AIDS

\begin{tabular}{ccc}
$\mathbf{N}=\mathbf{3 8 9}$ & $\mathbf{N}$ & Percentages (\%) \\
\hline Variables & & \\
Family History & 130 & 33.4 \\
Yes & 259 & 66.6 \\
No & 53 & 13.6 \\
Presence of Co-morbidities & 336 & 86.4 \\
Yes & & \\
No & 22 & 5.7 \\
Medical Insurance & 367 & 94.2 \\
Yes & 21 & 5.4 \\
No & 5 & 1.3 \\
Type of health insurance & 363 & 93.3 \\
Federal & & \\
State & & Mean \pm S.D \\
Not applicable & $\mathbf{N}$ & $1.7 \pm 2.6$ \\
& 389 & \\
No. of Hospitalization & & \\
HIV/AIDS & &
\end{tabular}

Table 3 shows the sociodemographic characteristics of participants' care givers. Almost all the participants had care givers $(91.8 \%)$ and these were mostly their spouses, children or sibling.

Tables 3 to 5 explored the association between sociode- mographic variables (gender, age, occupation, and marital status, level of education and presence of co morbidities) with the domains of quality of life for study participants. The domains of quality of life assessed were physical health, psychological health, social relationships and environmental. 
Table 3: Association of gender and age with the scores of the domains of quality of life among patients with HIV/AIDS

\begin{tabular}{|c|c|c|c|c|c|c|}
\hline \multicolumn{7}{|c|}{$\mathrm{N}=389$} \\
\hline $\begin{array}{l}\text { Domains of Quality of } \\
\text { Life }\end{array}$ & Gender & $\mathbf{N}$ & Mean \pm S.D & t-stat & df & p-value \\
\hline Physical Health & $\begin{array}{l}\text { Male } \\
\text { Female }\end{array}$ & $\begin{array}{l}120 \\
269\end{array}$ & $\begin{array}{l}74.7 \pm 16.2 \\
75.9 \pm 13.4\end{array}$ & -0.8 & 387 & 0.42 \\
\hline Psychological Health & $\begin{array}{l}\text { Male } \\
\text { Female }\end{array}$ & $\begin{array}{l}120 \\
269\end{array}$ & $\begin{array}{l}70.7 \pm 13.9 \\
74.2 \pm 13.4\end{array}$ & -2.4 & 387 & 0.01 \\
\hline Social Relationships & $\begin{array}{l}\text { Male } \\
\text { Female }\end{array}$ & $\begin{array}{l}120 \\
269\end{array}$ & $\begin{array}{r}74.7 \pm 17.4 \\
71.5 \pm 18.8\end{array}$ & 1.6 & 387 & 0.11 \\
\hline Environmental & $\begin{array}{l}\text { Male } \\
\text { Female }\end{array}$ & $\begin{array}{l}120 \\
269\end{array}$ & $\begin{array}{l}65.5 \pm 14.0 \\
61.1 \pm 15.5\end{array}$ & 2.7 & 387 & 0.007 \\
\hline $\begin{array}{l}\text { Domains of Quality of } \\
\text { Life }\end{array}$ & Age & $\mathbf{N}$ & Mean \pm S.D & F-stat & df & p-value \\
\hline Physical Health & $\begin{array}{l}18-25 \\
26-35 \\
36-45 \\
46-55 \\
56-65 \\
>65\end{array}$ & $\begin{array}{l}29 \\
113 \\
143 \\
71 \\
29 \\
4\end{array}$ & $\begin{array}{l}75.0 \pm 12.7 \\
78.9 \pm 13.2 \\
75.5 \pm 13.8 \\
73.6 \pm 15.5 \\
68.5 \pm 16.9 \\
73.2 \pm 4.6\end{array}$ & 3.0 & 5,383 & 0.01 \\
\hline Psychological Health & $\begin{array}{l}18-25 \\
26-35 \\
36-45 \\
46-55 \\
56-65 \\
>65\end{array}$ & $\begin{array}{l}29 \\
113 \\
143 \\
71 \\
29 \\
4\end{array}$ & $\begin{array}{l}69.1 \pm 13.2 \\
75.8 \pm 12.8 \\
72.9 \pm 13.8 \\
71.7 \pm 14.8 \\
69.7 \pm 11.8 \\
84.4 \pm 11.5\end{array}$ & $2.55,38$ & & 0.03 \\
\hline Social Relationships & $\begin{array}{l}18-25 \\
26-35 \\
36-45 \\
46-55 \\
56-65 \\
>65\end{array}$ & $\begin{array}{l}29 \\
113 \\
143 \\
71 \\
29 \\
4\end{array}$ & $\begin{array}{l}69.3 \pm 21.4 \\
72.5 \pm 19.5 \\
71.6 \pm 17.8 \\
74.2 \pm 19.0 \\
75.6 \pm 12.8 \\
72.9 \pm 18.4\end{array}$ & 0.6 & 5,383 & 0.76 \\
\hline Environmental & $\begin{array}{l}18-25 \\
26-35 \\
36-45 \\
46-55 \\
56-65 \\
>65\end{array}$ & $\begin{array}{l}29 \\
113 \\
143 \\
71 \\
29 \\
4\end{array}$ & $\begin{array}{l}61.6 \pm 15.0 \\
63.1 \pm 16.2 \\
60.9 \pm 15.6 \\
63.3 \pm 13.7 \\
64.1 \pm 12.6 \\
78.9 \pm 10.3\end{array}$ & $1.45,3$ & & 0.22 \\
\hline
\end{tabular}


Table 4: Association of marital status with the scores of the domains of quality of life among patients with HIV/AIDS

\begin{tabular}{|c|c|c|c|c|c|c|}
\hline \multicolumn{7}{|c|}{$\mathbf{N}=389$} \\
\hline Domains of Quality of Life & Marital Status & $\mathbf{N}$ & Mean \pm S.D & F-stat & df & p-value \\
\hline \multirow[t]{5}{*}{ Physical Health } & Single & 83 & $76.6 \pm 14.5$ & 1.4 & 4,384 & 0.22 \\
\hline & Married & 199 & $76.3 \pm 14.7$ & & & \\
\hline & Divorced & 7 & $74.5 \pm 17.8$ & & & \\
\hline & Separated & 9 & $67.1 \pm 14.0$ & & & \\
\hline & Widowed & 91 & $73.7 \pm 12.6$ & & & \\
\hline \multirow[t]{5}{*}{ Psychological Health } & Single & 83 & $71.4 \pm 13.6$ & 0.6 & 4,384 & 0.68 \\
\hline & Married & 199 & $73.5 \pm 14.1$ & & & \\
\hline & Divorced & 7 & $76.8 \pm 17.5$ & & & \\
\hline & Separated & 9 & $75.5 \pm 11.3$ & & & \\
\hline & Widowed & 91 & $73.3 \pm 12.7$ & & & \\
\hline \multirow[t]{5}{*}{ Social Relationships } & Single & 83 & $68.7 \pm 22.7$ & $5.24,3$ & 384 & $<0.001$ \\
\hline & Married & 199 & $76.5 \pm 15.9$ & & & \\
\hline & Divorced & 7 & $70.2 \pm 22.0$ & & & \\
\hline & Separated & 9 & $63.0 \pm 18.2$ & & & \\
\hline & Widowed & 91 & $68.3 \pm 17.4$ & & & \\
\hline \multirow[t]{5}{*}{ Environmental } & Single & 83 & $64.8 \pm 15.4$ & 3.0 & 2,117 & 0.02 \\
\hline & Married & 199 & $63.6 \pm 15.4$ & & & \\
\hline & Divorced & 7 & $51.3 \pm 24.9$ & & & \\
\hline & Separated & 9 & $59.7 \pm 14.9$ & & & \\
\hline & Widowed & 91 & $59.0 \pm 13.1$ & & & \\
\hline
\end{tabular}

Table 5: Association of level of education and presence of co-morbidities with the scores of the domains of quality of life among patients with HIV/AIDS

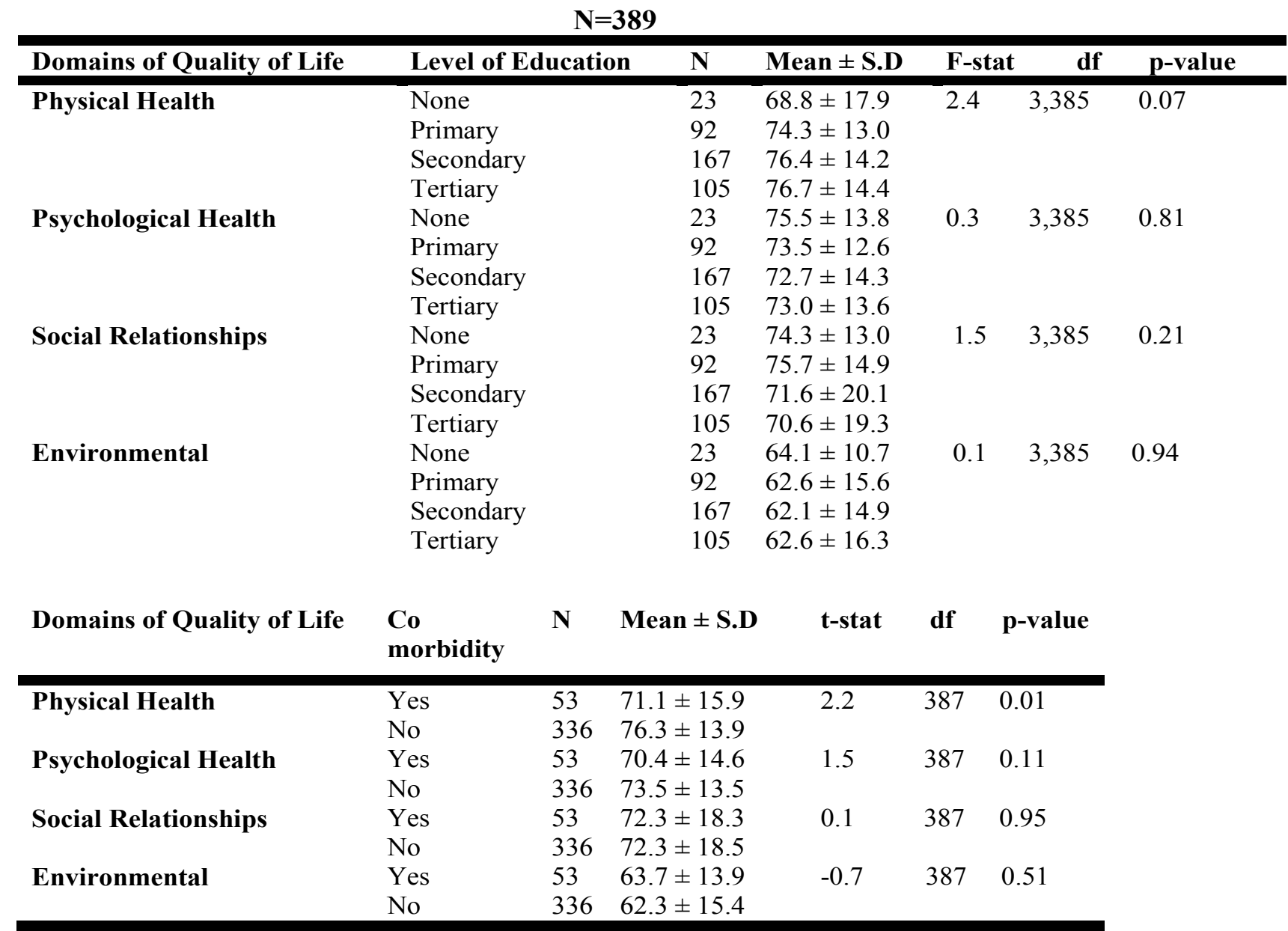


Females had a higher score with respect to the domain of psychological health while males had a higher score with respect to the environmental domain. These findings were significant ( $p$ value 0.01 and 0.007 respectively). Participants aged 18-45years had a higher score with respect to physical health while age 26-45years had a higher score for psychological health. Thus, age showed significant affectation across the domains of physical and psychological health.

Although housewives had a higher score for social relationships, they had a low score for psychological health. Being married was positively associated with participants social relationships while the presence of co morbidities affected participants' physical health significantly. There was no significant association between participants' level of education and quality of life.
There was also a significant association between level of education and presence of co-morbidity with participants' physical health.

In the multiple regression analysis, those variables that were significantly correlated with the dependent or criterion variable (for example, physical health domain), age, presence of comorbidities, no of hospitalization, no of dependents, were entered as predictors into the regression using the standard method (Enter). A significant model emerged: $F(4,608)=6.66, \mathrm{p}<0.001$. The model explains $16.5 \%$ (adjusted $\mathrm{R}$ square $=0.165$ ). Table 6 gives information about regression coefficients and the variance for the predictor variables entered into the model. Age of participants, number of dependents, number of hospitalization, presence of comorbidities were significant predictors of health-related quality of life-physical health domain, with positive relationship to number of dependents and the others negative relationship

Table 6: Summary of regression result of the socio-demographic and clinical predictors of quality of life in the four domains among people with HIV/AIDS

\begin{tabular}{|c|c|c|c|c|c|}
\hline Dependent variable & Significant predictors & $\begin{array}{l}\text { Standardized } \\
\beta \text { coefficient }\end{array}$ & t-stat & $\begin{array}{l}p \text { - } \\
\text { value }\end{array}$ & Variance $(\%)$ \\
\hline \multirow{5}{*}{$\begin{array}{l}\text { Total Physical Health } \\
\text { Domain Score }\end{array}$} & Age of participants & -0.18 & -3.15 & 0.002 & 2.1 \\
\hline & Number of dependents & 0.14 & 2.63 & 0.009 & 3.3 \\
\hline & $\begin{array}{l}\text { Number } \\
\text { hospitalization }\end{array}$ & -0.13 & -2.50 & 0.013 & 4.5 \\
\hline & $\begin{array}{l}\text { Presence } \\
\text { comorbidities }\end{array}$ & -0.11 & -2.24 & 0.026 & 5.5 \\
\hline & \multicolumn{3}{|l|}{ F-stat. $=6.66 ; \mathrm{df}=4,384$} & \multicolumn{2}{|c|}{$\operatorname{Prob}($ F-stat. $)=0.000$} \\
\hline Dependent variable & Significant predictors & $\begin{array}{l}\text { Standardized } \\
\beta \text { coefficient }\end{array}$ & t-stat & $\begin{array}{l}p- \\
\text { value }\end{array}$ & Variance (\%) \\
\hline \multirow{3}{*}{$\begin{array}{l}\text { Total Psychological } \\
\text { Health Domain Score }\end{array}$} & Gender & 0.15 & 2.99 & 0.003 & 1.2 \\
\hline & No of dependents & 0.15 & 2.95 & 0.003 & 3.1 \\
\hline & \multicolumn{3}{|l|}{ F-stat. $=7.27 ; \mathrm{df}=2,386$} & \multicolumn{2}{|c|}{$\operatorname{Prob}($ F-stat. $)=0.001$} \\
\hline Dependent variable & Significant predictors & $\begin{array}{l}\text { Standardized } \\
\beta \text { coefficient }\end{array}$ & t-stat & $\begin{array}{l}p- \\
\text { value }\end{array}$ & Variance (\%) \\
\hline \multirow{4}{*}{$\begin{array}{lr}\text { Total } & \text { Social } \\
\text { Relationship } & \text { Domain } \\
\text { Score } & \end{array}$} & No of dependent & 0.14 & 2.85 & 0.005 & 1.7 \\
\hline & Marital status & -0.14 & -2.69 & 0.007 & 2.6 \\
\hline & Level of education & -0.12 & -2.33 & 0.020 & 3.7 \\
\hline & \multicolumn{3}{|l|}{ F-stat. $=8.57 ; \mathrm{df}=3,385$} & \multicolumn{2}{|c|}{$\operatorname{Prob}($ F-stat. $)=0.001$} \\
\hline Dependent variable & Significant predictors & $\begin{array}{l}\text { Standardized } \\
\beta \text { coefficient }\end{array}$ & t-stat & $\begin{array}{l}p \text { - } \\
\text { value }\end{array}$ & Variance (\%) \\
\hline \multirow{4}{*}{$\begin{array}{l}\text { Total environmental } \\
\text { domain Score }\end{array}$} & Gender & -0.11 & -0.05 & 0.041 & 7.7 \\
\hline & Marital status & -0.15 & -2.86 & 0.004 & 1.9 \\
\hline & No of hospitalization & 0.23 & 4.70 & 0.000 & 6.9 \\
\hline & \multicolumn{3}{|c|}{ F-stat. $=11.75 ; \mathrm{df}=3,385$} & \multicolumn{2}{|c|}{$\operatorname{Prob}($ F-stat. $)=0.000$} \\
\hline
\end{tabular}


The overall quality of life score in response to the question about satisfaction with life was 4.05(Range 1-5, of 0-5(Table 7).

Table 7: Domain scores and overall quality of life scores of people living with HIV/AIDS

\begin{tabular}{lclrcc}
\hline Domains & N & Range & Mean & $\begin{array}{l}\text { Standard } \\
\text { Deviation }\end{array}$ & 95\%Confidence Interval \\
\hline Domain 1 & 389 & $\begin{array}{l}11- \\
100\end{array}$ & 75.55 & 14.28 & $74.83-76.27$ \\
Domain 2 & 389 & $\begin{array}{l}21- \\
100\end{array}$ & 73.11 & 13.65 & $72.42-73.80$ \\
Domain 3 & 389 & $0-100$ & 72.47 & 18.44 & $71.53-73.41$ \\
Domain 4 & 389 & $9-100$ & 62.46 & 15.20 & $61.69-63.23$ \\
Overall QoL & 389 & $1-5$ & 4.05 & 0.04 & $4.01-4.09$ \\
\hline
\end{tabular}

\section{Discussion}

In our study, proportion of patients by gender showed more females with HIV (69.2\%) than males $(30.8 \%)$ and majority were married (51.2\%). Although some researchers opine that high risk sexual behavior is more common among young $\operatorname{men}^{24}$, data from other sources have indicated that Black/African American women are disproportionately affected by HIV, compared with women of other races/ethnicities ${ }^{25}$ and a recent study carried out in the Nigerian Institute of Medical Research ART Clinic lends credence to this ${ }^{26}$.

The reasons for this disparity are not far-fetched. Generally, receptive sex is riskier than insertive sex thereby creating a higher risk for getting HIV during vaginal or anal sex for women than their sex partners. Furthermore, because some women may be unaware of their male partner's risk factors for HIV (such as injection drug use or having sex with men), they may not use condoms.

In Nigeria specifically, certain factors fuel the relatively high prevalence of the HIV/AIDS epidemic among vulnerable groups which include women. These include poverty, migration, harmful traditional practices, social status of women, unwholesome marriage practices, sanctity and sacredness of sex, idol marriage or cult prostitution, infertility or sterility factor, sexual violence, communal conflict and wars, unemployment, holding brief, and illiteracy and most of them were related to poverty ${ }^{27}$.

Participants aged between 18 and 45 years constituted over $70 \%$ of the patients with HIV and this finding is consistent with epidemiological studies on the disease where HIV has been documented to affect young people disproportionately ${ }^{28}$. This age group represents a critical productive age group and working class population. HIV may still impact negatively on economic prospects of young people in the community.

About half of our participants earn 10,000NGN (about $\$ 27 \mathrm{USD}$ ) or less. This is the category of extreme poverty (people living on $<\$ 1.9 /$ day) for which Nigeria recently topped the list as the country with the most population in extreme poverty $(44.2 \%)^{29}$. For a disease like HIV which has potentials for complications and drug-drug interactions especially in the presence of co-morbidities and in a country where payment for health is largely out-of-pocket, as supported by the fact that less than $6 \%$ of participants have medical insurance, morbidity and mortality for these patients is a concern. This is because, although provision of anti-retroviral therapy is free from donors and supported by the Nigerian government, these patients are at greater risk of noninfectious comorbidities, including cardiovascular and renal diseases ${ }^{30}$.

Our study showed that being married was associated with a higher quality of life score for social relationships and even on regression analysis, this finding was still significant. This finding is consistent with reports from a similar study carried out in South-west Nigeria ${ }^{20}$. The family setting, especially in Africa where the extended family system still functions effectively, provides security, safety and financial support. Thus, this finding may be explained by the fact that people in a marital relationship are more likely to enjoy better social support and closer interpersonal relationships. Stigma, discrimination and lack of support have been reported to be more common in widowed or separated women in a study carried out in rural India ${ }^{31}$. Age significantly impacted on participants' quality of 
health across two domains, physical and psychological helath. This is a key finding of our study. Older patients had lower quality of health in the physical health domain while younger patients were more affected in the psychological domain. The latter finding may be explained by older patients being probably more affected by comorbid health conditions. HIV infected patients are at greater risk for noninfectious comorbidities (NICMs) such as cardiovascular disease, hypertension, diabetes mellitus, bone fractures and renal failure, compared with the general population ${ }^{32}$. In this study however, only $13.6 \%$ reported one or more co-morbid medical conditions.

HIV infected patients are also more likely to have polypathology (the concurrent presence of two or more NICMs) and age was found to be an independent predictor for polypathology $y^{32}$. It stands to reason, therefore, that older HIV infected patients are more likely to have impairment in their physical health. Infact, our study showed a significant affectation in the domain of physical health amongst participants with co-morbidities. Conversely, younger HIV patients are more likely to have psychological issues as they are faced with problems of disclosure, fear of an unknown future with possible complications from disease, financial worries and coping issues. Age of participants, presence of comorbidities, number of dependents and number of hospitalizations, were socio-demographic factors that significantly affected the domain of physical health on regression analysis.

Using the average cut -off score of 78 obtained in South West Nigeria, most of the HIV patients in this study scored below the national average and thus have reduced health related quality of life in all the domains assessed. The deterioration in quality of life was least in physical health domain but worst for environmental health domain. No reason can easily be adduced for this finding but it may be related to poorer socioeconomic indices in the South East region as well as overall poorer health indices due to the primary infection, though CD4 counts and viral loads were not assessed in this study to gauge immuno-competence and good disease control.

\section{Conclusion}

HIV has been transformed into a chronic disease with available combination antiretroviral therapy with life expectancy approaching that of the general population. However, health related quality of life is said to be low- er in patients with HIV, despite good viral suppression. Our study showed that adult patients with HIV infection and receiving ART in Enugu, South East Nigeria, have reduced quality of life in all domains. Females and young people $\leq 45$ years of age carry the heavier burden. Age and presence of comorbidities were significant predictors.

A major implication for policy making is the need to integrate mental health services in HIV care and treatment especially with regards to the younger patients. Early detection of psychological problems and provision of appropriate therapeutic support for affected patients is vital as part of the clinical decisions needed in the management of HIV patients. Older patients with HIV should be monitored closely in order to identify and institute treatment for non infectious comorbidities early in the course of the disease.

Findings from this study may not be generalizable to HIV patients in Nigeria but we hope this study will serve as a background for further HRQoL studies in the south eastern part of Nigeria.

\section{Study strengths}

One strength of this study is that it assesses the quality of life of HIV patients in our center and it is hoped that findings from this study can be translated into policy.

\section{Study limitations}

Randomization was not carried out in the sampling design and so this may have led to sampling bias. No specific measures were taken to address any observed heterogeneity among study participants.

It was not possible to inculcate patients CD4 counts and viral loads as components of this study due to logistic constraints. This is a major limitation of our study as information from these values would have helped to understand our patient cohort on the basis of severity of disease.

\section{Acknowledgments}

The authors are grateful to the nursing staff of the HIV clinic of the University of Nigeria Teaching Hospital, Enugu, for their cooperation in the study.

\section{Authors' contributions}

All authors participated in the conceptualization of the study and collaborated in the design. NRC and NC collected the data. UN oversaw the data analysis. OCL and 
OI wrote the manuscript while all authors reviewed and approved the final draft. Funding was contributed to by the authors. OI is the guarantor of the manuscript.

\section{Conflict of interest}

None declared.

\section{References}

1. Deeks SG, Lewin SR, Havlir DV. The End of AIDS: HIV Infection as a Chronic Disease. Lancet. 2013 Nov 2; 382(9903):1525-1533

2. UNAIDS. Nigeria-Overview. 2018. Available from: http://www.unaids.org/en/regionscountries/ countries/nigeria ( Accessed 6th December, 2018)

3. Awofala AA, Ogundele OE. HIV Epidemiology in Nigeria. Saudi Journal of Biological Sciences Volume 25(4), 2018;pp697-703

4. Uzochukwu BS, Ughasoro MD, Etiaba E, Okwuosa C, Envuladu E, Onwujekwe OE. Health care financing in Nigeria: Implications for achieving universal health coverage. Niger J Clin Pract. 2015 Jul-Aug; 18 (4):437-44. doi: 10.4103/1119-3077.154196

5. Onwujekwe OE, Uzochukwu BS, Obikeze EN, Okoronkwo I, Ochonma OG, Onoka CA, Madubuko G, Okoli C. Investigating determinants of out-of-pocket spending and strategies for coping with payments for healthcare in southeast Nigeria. BMC Health Serv Res. 2010 Mar 17;10:67. doi: 10.1186/1472-6963-10-67.

6. Habib SS, Perveen S, Khuwaja HM The role of micro health insurance in providing financial risk protection in developing countries--a systematic review. BMC Public Health. 2016 Mar 22;16:281. doi: 10.1186/s12889016-2937-9

7. The World Health Report: Health System Financing: The Path To Universal Coverage. 2010. http:/ /www. who.int/whr/2010/whr10_en.pdf. (Accessed 6th December, 2016)

8. Miners A, Phillips A, Kreif N, Rodger A, Speakman A, Fisher $\mathrm{M}$ et al. Health-related quality-of-life of people with HIV in the era of combination antiretroviral treatment: a cross-sectional comparison with the general population. Science Direct. 2014;1: 32-40

9. Leach-Lemens C. Life expectancy for people with HIV in Africa may be comparable to general population if they are on treatment. Available from:http://www. aidsmap.com/Life-expectancy-for-people-with-HIVin-Africa-may-be-comparable-to-general-population-if- they-are-on-treatment/page/1878715/

(Accessed:6th

December, 2018)

10. Ware JE, Jr Kosinski M, Bayliss MS, McHorney CA, Rogers WH, Raczek A. Comparison of methods for the scoring and statistical analysis of SF-36 health profile and summary measures: Summary of results from the Medical Outcomes Study. Med Care. 1995;33(4 Suppl):AS264-279.

11. Wu AW, Hays RD, Kelly S, Malitz F, Bozzette SA. Applications of the Medical Outcomes Study health-related quality of life measures in HIV/AIDS. Qual Life Res. 1997;6:531-554.

12. Connell J, Brazier J, O’Cathain A, Lloyd-Jones M, Paisley S. QoL of people with mental health problems: a synthesis of qualitative research. Health and QoL Outcomes. 2012;10:138

13. Sherbourne CD, Hays RD, Fleishman JA. Impact of psychiatric conditions on health-relatedQoL in persons with HIV infection. Am J Psychiatry. 2000;157:248254

14. Perkins DO, Stern RA, Golden RN, Murphy C, Naftolowitz D, Evans DL. Mood disorders in HIV infection: prevalence and risk factors in a non-epicenter of the AIDS epidemic. Am J Psych.1994;151:233-236

15. Bing EG, Hays RD, Jacobson LP, Chen B, Gange SJ, Kass NE et al . Health-related quality of life among people with HIV disease: results from the Multicenter AIDS Cohort Study. Qual Life Res. 2000;9:55-63.

16. Hays RD, Cunningham WE, Sherbourne CD, Wilson IB, Wu AW, Cleary PD et al. Health-related quality of life in patients with human immunodeficiency virus infection in the United States: results from the HIV Cost and Services Utilization Study. Am J Med. 2000;108:714722.

17. Ruiz Perez I, Rodriguez Baño J, Lopez Ruz MA, del Arco Jimenez A, Causse Prados M, Pasquau Liaño J et al . Health-related quality of life of patients with HIV: Impact of sociodemographic, clinical and psychosocial factors. Qual Life Res.2005;14:1301-1310.

18. Thomas R, Burger R, Harper A, Kanema S, Mwenge L, Vanqa $\mathrm{N}$ et al. Differences in health-related quality of life between HIV-positive and HIV-negative people in Zambia and South Africa; a cross-sectional baseline survey of the HPTN 071(PopART) trial. Lancet Glob Health 2017;5:e1133-41

19. N Mafirakureva, B Dzingirai, M.J. Postma, M.van Hulst \& S. Khoza Health-related quality of life in HIV/ 
AIDS patients on antiretroviral therapy at a tertiary care facility in Zimbabwe. AIDS Care. 2016;28:7,904-912.

20. Akinboro AO, Akinyemi SO, Olaitan PB, Raji AA, Popoola AA, Awoyemi OR et al. Quality of life of Nigerians living with human immunodeficiency virus. Pan Afri Med J. 2014;18:234

21. The World Health Organization Quality of Life Assessment(WHOQOL):development and general psychometric properties. Soc Sci Med. 1998;46:1569-1585 PubMed

22. Onwuekwe IO, Unaogu N, Aguwa EN, Ezeala-Adikaiabe B. Health-Related Quality of Life and its Determinants in Adult Nigerians with Epileptic Seizures. Austin J Neurol Disorder Epilepsy. 2015;2(1):1013 PubMed 23. Akinyemi OO, Owoaje ET, Popoola OA, Ilesanmi OS. Quality of Life and Associated Factors among Adults in a Community inSouth West Nigeria. Ann Ib Postgrad Med. 2012;10(2):34-29.

24. Bremner, J., C. Haub, M. Lee, M. Mather and E. Zuehlke, 2009. World population highlights: Key findings from PRB's 2009 world population data sheet. Popul. Bull., 64(3): 2-12.

25. CDC. Diagnoses of HIV infection in the United States and dependent areas, 2016. HIV Surveillance Report 2017; 28. Available at: https://www.cdc.gov/hiv/ pdf/library/reports/surveillance/cdc-hiv-surveillancereport-2016-vol-28.pdf [Accessed May 1, 2018].

26. Jinadu MY, Aghahowa EE, Ogunsina OO, Musa AZ Current Sociodemographics of HIV Infected Adults in Lagos. Nigeria Acta Scientific Microbiology 1.2 (2018): 21 23

27. Eneh, OC and Ugwu, DS Socio-Cultural Factors Fuelling HIVand AIDS And Their Relationships With Rural Poverty In Nigeria. Knowledge Review. 17. 11-16. Available at: https://www.researchgate.net/ publication/281275688_SOCIO-CULTURAL_FACTORS_FUELLING_HIV_AND_AIDS_AND_ THEIR_RELATIONSHIPS_WITH_RURAL_POVERTY_IN_NIGERIA [Accessed MAY 1, 2018]

28. Awofala AA,Ogundele OE HIV epidemiology in Nigeria Saudi J Biol Sci 2016 http:/ /dx.doi.org/10.1016/j. sjbs.2016.03.006

29. World Poverty Clock. June 2018 Report. https:// worldpoverty.io (Accessed 25 June 2018).

30. Rodriguez-Penney AT, Ludicello JE, Riggs PK, Doyle K, Ellis RJ, Letendre SL et al. Co-Morbidities in Persons infected with HIV: Increased Burden with Older Age and Negative Effects on Health-Related Quality of Life. AIDS Patient Care STDS. 2013;27(1):5-16

31. Alvarez-Uria G, Midde, Naik PK Socio-demographic Risk Factors Associated with HIV infection in Patients Seeking Medical Advice in a Rural Hospital in India. J Public Health Res. 2012;1(1)79-82

32. Guaraldi G, Orlando G, Zona S, Menozzi M, Carli F, Garlassi E et al. Premature Age-Related Comorbidities Among HIV-Infected Persons Compared With the General Population. Clinical Infectious Diseases 2011;53:11201126 